\title{
Editorial: Conservation of European Freshwater Crayfish
}

\author{
Kathrin Theissinger ${ }^{1 *}$, Lennart Edsman ${ }^{2}$, Ivana Maguire ${ }^{3}$, Javier Diéguez-Uribeondo ${ }^{4}$ and \\ Japo Jussila ${ }^{5}$ \\ ${ }^{1}$ Landes-Offensive zur Entwicklung Wissenschaftlich-ökonomischer Exzellenz Centre for Translational Biodiversity Genomics, \\ Senckenberg Biodiversity and Climate Research Centre, Frankfurt, Germany, ${ }^{2}$ Department of Aquatic Resources, Institute of \\ Freshwater Research, Swedish University of Agricultural Sciences, Drottningholm, Sweden, ${ }^{3}$ Department of Biology, Faculty \\ of Science, University of Zagreb, Zagreb, Croatia, ${ }^{4}$ Department of Mycology, Real Jardín Botánico-Consejo Superior de \\ Investigaciones Cientificas, Madrid, Spain, ${ }^{5}$ Department of Environmental and Biological Sciences, University of Eastern \\ Finland, Kuopio, Finland
}

Keywords: crayfish ecology, invasive species management, disease control, aquaculture, conservation, restocking

\section{Editorial on the Research Topic}

\section{Conservation of European Freshwater Crayfish}

Freshwater ecosystem functioning is often thought to be dominated by fish, determining the community structure via top-down control and ecosystem engineering. However, freshwater crayfish can have an even stronger effect on food web and ecosystem functioning, operating as keystone species in a water body (Longshaw and Stebbing, 2016). As environmental engineers, crayfish have a significant impact on the biodiversity within their habitat (Souty-Grosset et al., 2006). Yet over the past 150 years freshwater crayfish in Europe have faced a novel challenge in the form of a lethal disease caused by the oomycete Aphanomyces astaci Schikora 1906, introduced

\section{OPEN ACCESS}

Edited and reviewed by:

Alison G. Nazareno,

Federal University of Minas

Gerais, Brazil

${ }^{*}$ Correspondence:

Kathrin Theissinger

kathrin.theissinger@senckenberg.de

Specialty section:

This article was submitted to

Evolutionary and Population Genetics,

a section of the journal

Frontiers in Ecology and Evolution

Received: 29 October 2021 Accepted: 10 November 2021 Published: 30 November 2021

Citation:

Theissinger K, Edsman L, Maguire I,

Diéguez-Uribeondo J and Jussila J (2021) Editorial: Conservation of European Freshwater Crayfish.

Front. Ecol. Evol. 9:804629. doi: 10.3389/fevo.2021.804629 by alien crayfish species of North American origin. Today, the European native crayfish population trends are in decline nearing extinction in several cases (Souty-Grosset et al., 2006; Jussila et al., 2014).

The introduction of different $A$. astaci strains in Europe and the repeated introductions of their North American host species are a classic example of a man-made ecological disaster (Jussila et al.), stemming from the naive belief that the manipulation of an ecosystem would be straightforward. The alien crayfish species, which were supposed to replace the eradicated native stocks, not only transfer the deadly disease but in many parts of Europe also outcompete their native crayfish counterparts, because they are more aggressive giving them additional advantage regarding habitat competition in addition to higher fecundity (Alonso and Martínez, 2006). Introductions of new alien crayfish stocks and thus new $A$. astaci strains will inevitably lead to the total eradication of the remaining native European crayfish stocks.

In this Research Topic we collected scientific work on crayfish conservation from multiple scales, ranging from molecular to species and ecosystem levels, to address the consequences of invasive crayfish and host-parasite interactions on European freshwater biodiversity and ecosystem functioning, aiding conservation and management of European freshwater crayfish to prevent them from extinction.

\section{CRAYFISH MANAGEMENT AND RE-INTRODUCTIONS}

Effective management of both endangered native and invasive alien crayfish requires knowledge about distribution, monitoring of existing and early detection of newly established populations. Krieg et al. provided an overview on various management practices to control invasive crayfish in 
Switzerland. They highlight the great challenges and limitations of such measures like eradication, suppression and containment, and give valuable recommendations for effective invasive crayfish control. Dams are often regarded as effective planning measures to prevent invasive aquatic species spread and to protect the native aquatic fauna, but the effects of dams on crayfish populations have not been thoroughly evaluated. The review by Barnett and Adams outlines that dams can have both beneficial and detrimental effects on crayfish population dynamics.

The underlying mechanisms of native crayfish recovery following biological invasions or their coexistence with invasive species are not clearly determined (Nyström et al., 2001; Kats and Ferrer, 2003; Rodriguez, 2006). It was suggested that the success of invasive over native crayfish represents the synergic interaction of multiple factors. One aspect is the superior competition for resources of the invasive vs. native crayfish (Pacioglu et al., 2020). The study by Parvulescu et al. showed that in interspecific agonistic interactions, the behavior strategy of the invasive crayfish species is based on sheer physical superiority, whereas the native narrow-clawed crayfish relies on intimidation display.

Over the last decades, genetic tools have proven highly beneficial as supplementary tools in biodiversity monitoring. Chucholl et al. provided a novel set of specific eDNA-assays for all native and the most relevant invasive crayfish species in Central Europe, and the efficiency of these assays was assessed regarding the influence of spatio-temporal variables such as distance to upstream population, season and stream size. They show that eDNA-detection is a highly suitable complementary monitoring tool for crayfish, particularly for a large-scale screening of data-deficient catchments or a yearround monitoring. Johnsen et al. proved that eDNA is highly reliable for presence-absence monitoring of noble crayfish, while it cannot substitute the traditional catch per unit effort data, especially for low density populations.

In a study on genetic populations by Martín-Torrijos, Correa-Villalona, Pradillo, et al. new patterns of genetic diversity of the native white-clawed crayfish of the Iberian Peninsula showed the potential effect of paleogeographic barriers on its population structure. The authors suggest that current conservation and management programs should consider three phylogeographic groups as essential management units in order to preserve the remaining genetic diversity, which is critically threatened by crayfish plague (MartínTorrijos et al., 2019). It has been shown for many crayfish species that there are significant differences regarding the genetic diversity across Europe, and that restocking programs should always consider the natural genetic make-up of the populations (e.g., Schrimpf et al., 2014, 2017; Lovrenčić et al., 2020; Dannewitz et al., 2021). For restocking purposes, conservationists rely on efficient crayfish breeding systems. Regarding the endangered white-clawed crayfish, Nightingale et al. present the optimal diet for rearing endangered whiteclawed crayfish. They showed that live food is optimal for high survival and growth in hatchlings as a diet based on plankton and vegetable matter is most beneficial. These results are important for captive breeding success prior to reintroductions.
Manenti et al. outlined an impressive example of a successful reintroduction of the endangered white-clawed crayfish in Italy, after a crayfish plague population collapse caused by the presence of alien crayfish. They showcase the importance of public awareness and stakeholder involvement to enhance the success of such reintroductions. But not only invasive alien crayfish pose a risk to native crayfish fauna. In a study by Tricarico et al. it is highlighted for the first time that invasive raccoons prey on crayfish and pose a severe risk of extinction for the endangered native white-clawed crayfish in Central Italy.

The study by Boštjančić et al. showcase that the high content and diversity of repetitive elements in the genome of the native narrow-clawed crayfish may have provided a driving force for the genome evolution of this native European crayfish. This cytogenomic approach could enhance future studies of other native crayfish species by revealing their evolutionary history and phylogenetic relations.

\section{CRAYFISH PLAGUE MANAGEMENT}

The detection of the crayfish plague disease agent $A$. astaci within water bodies is of extreme importance for successful freshwater crayfish management, in addition to the presence or absence detection of invasive crayfish. This oomycete shows a high variability in its virulence among different haplogroups (Makkonen et al., 2012, 2014, 2018; Martín-Torrijos et al., 2021). Thus, it is crucial to monitor not only the distribution of the pathogen, but also to determine its genetic group to infer its virulence and thus the consequences to the affected crayfish populations. The study by Di Domenico et al. now provides a novel set of sensitive and highly specific qPCR assays as a robust tool for fast genotyping of $A$. astaci genotype groups common in Europe.

The controlled infection experiment by Francesconi et al. provided additional evidence of how drastically strains of A. astaci differ in their virulence. This study confirmed the adaptation of one specific $A$. astaci haplogroup to their novel European hosts, supposedly due to ongoing coevolution (Jussila et al., 2021) as confirmed by transcriptomic data analyses (Boštjančić et al., 2021). Furthermore, Francesconi et al. experimentally showed that invasive marbled crayfish are remarkably resistant against the crayfish plague disease and could potentially be latently infected, acting as carriers of highly virulent $A$. astaci strains.

In addition to differing virulence levels among $A$. astaci strains, Martín-Torrijos, Correa-Villalona, Azofeifa-Solano, et al. confirmed the presence of the red swamp crayfish associated $A$. astaci strain in coastal habitats, while so far it has been assumed that $A$. astaci is not viable in brackish waters. This finding is of high concern for the conservation of European native freshwater crayfish and highlights once more the risk of introducing invasive alien crustaceans. The crayfish plague pandemic is not only threatening the European freshwaters, as A. astaci is spreading worldwide due to globalization and pet trade. Martín-Torrijos, Buckley, et al. report the first-time detection of A. astaci in Costa Rica, and give valuable recommendations of invasive red swamp 
crayfish management in line with experiences from the European continent, to intervene the detrimental impacts of $A$. astaci on native decapod species in Central America.

\section{MONEY KILLS NATIVE ECOSYSTEMS: EUROPEAN CRAYFISH AS AN EXAMPLE}

For the past 150 years, the European crayfish fauna has been devastated by the crayfish plague. As an attempt to economically compensate for this decline, alien North American crayfish such as signal crayfish, have been deliberately released into European water courses. However, the mass mortality of native crayfish has accelerated rather than slowed down as a result. Jussila et al. explain in their Policy and Practice review how this has happened, and which lessons can be learned from this. The case of the European crayfish serves as a particularly evident example of how the introduction of non-native species to replace lost native populations ended up doing more harm than good. Science-based warnings about alien species damage to native ecosystems and native crayfish must

\section{REFERENCES}

Alonso, F., and Martínez, R. (2006). Shelter competition between two invasive crayfish species: a laboratory study. Bull. Franç. Pêche Piscicult. 380-381, 1121-1132. doi: 10.1051/kmae:2006015

Boštjančić, L. L., Francesconi, C., Rutz, C., Hoffbeck, L., Poidevin, L., Kress, A., et al. (2021). Comparative transcriptomics analysis of noble crayfish and marbled crayfish immune response to crayfish plague disease. bioRxiv. doi: 10.1101/2021.05.25.44 5163

Dannewitz, J., Palm, S., and Edsman, L. (2021): Colonization history and human translocations explain the population genetic structure of the noble crayfish (Astacus astacus) in Fennoscandia: implications for the management of a critically endangered species. Aquat. Conserv. Mar. Freshw. Ecosyst. 31, 1970-1982. doi: 10.1002/aqc. 3632

Jussila, J., Francesconi, C., Theissinger, K., Kokko, H., and Makkonen, J. (2021). Is Aphanomyces astaci losing its stamina: a latent crayfish plague disease agent from lake Venesjärvi, Finland. Freshw. Crayfish. [in print].

Jussila, J., Makkonen, J., Vainikka, A., Kortet, R., and Kokko, H. (2014). Crayfish plague dilemma: how to be a courteous killer? Boreal Environ. Res. 19, 235-244.

Kats, L. B., and Ferrer, R. P. (2003). Alien predators and amphibian declines: review of two decades of science and the transition to conservation. Diver. Distribut. 9, 99-110. doi: 10.1046/j.1472-4642.2003.00013.x

Longshaw, M., and Stebbing, P. O. (2016). Biology and Ecology of Crayfish. New York, NY: CRC Press. doi: 10.1201/b2 0073

Lovrenčić, L., Bonassin, L., Boštjančić, L., Podnar, M., Jelić, M., Klobučar, G., et al. (2020). New insights into the genetic diversity of the stone crayfish: taxonomic and conservation implications. BMC Evolut. Biol. 20:146. doi: 10.1186/s12862-020-01 709-1

Makkonen, J., Jussila, J., Kortet, R., Vainikka, A., and Kokko, H. (2012). Differing virulence of Aphanomyces astaci isolates and elevated resistance of noble crayfish Astacus astacus against crayfish plague. Dis. Aquat. Organ. 102, 129-136. doi: 10.3354/dao0 2547

Makkonen, J., Jussila, J., Panteleit, J., Keller, N. S., Schrimpf, A., Theissinger, K., et al. (2018). MtDNA allows the sensitive detection and haplotyping of the be taken seriously and with utmost caution. Protection of native European crayfish is the core issue but not the commercial activities. Finally, Jussila et al. summarize main threats and actions needed to protect remaining native freshwater crayfish fauna in Europe, with emphasis on the halt of alien species spread by stronger EU regulations and law enforcements as well as public awareness initiatives to connect people back to nature.

\section{AUTHOR CONTRIBUTIONS}

All authors listed have made a substantial, direct, and intellectual contribution to the work and approved it for publication.

\section{ACKNOWLEDGMENTS}

We would like to thank the whole freshwater crayfish network in Europe and beyond for the great science, support, comments, and reviews to make this Research Topic on Conservation of European Freshwater Crayfish happen.

crayfish plague disease agent Aphanomyces astaci showing clues about its origin and migration. Parasitology 145, 1210-1218. doi: 10.1017/S003118201800 0227

Makkonen, J., Kokko, H., Vainikka, A., Kortet, R., and Jussila, J. (2014). Dose-dependent mortality of noble crayfish (Astacus astacus) to different strains of the crayfish plague (Aphanomyces astaci). J. Invertebr. Pathol. 115, 86-91. doi: 10.1016/j.jip.2013.1 0.009

Martín-Torrijos, L., Kokko, H., Makkonen, J., Jussila, J., and DiéguezUribeondo, J. (2019). Mapping 15 years of crayfish plague in the Iberian Peninsula: the impact of two invasive species on the endangered native crayfish. PLOS ONE 14:e0219223. doi: 10.1371/journal.pone.021 9223

Martín-Torrijos, L., Martínez-Ríos, M., Casabella-Herrero, G., Adams, S. B., Jackson, C. R., and Diéguez-Uribeondo, J. (2021). Tracing the origin of the crayfish plague pathogen, Aphanomyces astaci, to the Southeastern United States. Sci. Rep. 11:9332. doi: 10.1038/s41598-021-88 704-8

Nyström, P., Svensson, O., Lardner, B., Brönmark, C., and Granéli, W. (2001). The influence of multiple introduced predators on a littoral pond community. Ecology 81, 1023-1039. doi: 10.1890/0012-9658(2001)0821023:TIOMIP2.0.CO;2

Pacioglu, O., Theissinger, K., Alexa, A., Samoila, C., Schulz, R., Schrimpf, A., et al. (2020). Multifaceted implications behind the competition of native and invasive crayfish: a glimmer of hope for the native's longterm survival? Biol. Invasions 22, 827-842. doi: 10.1007/s10530-019-02 136-0

Rodriguez, L. F. (2006). Can invasive species facilitate native species? Evidence of how, when, and why these impacts occur. Biol. Invasions 8, 927-939. doi: 10.1007/s10530-005-5 103-3

Schrimpf, A., Piscione, M., Cammaerts, R., Herman, D., Collas, M., Jung, A., et al. (2017). Genetic characterization of Western European noble crayfish populations (Astacus astacus) for advanced conservation management strategies. Conserv. Genet. 18, 1299-1315. doi: 10.1007/s10592-017-0 981-3

Schrimpf, A., Theissinger, K., Dahlem, J., Maguire, I., Parvulescu, L., Schulz, H. K., et al. (2014). Phylogeography of noble crayfish (Astacus astacus) reveals multiple refugia. Freshw. Biol. 59, 761-776. doi: 10.1111/fwb.1 2302 
Souty-Grosset, C., Holdich, D. M., Noël, P. Y., Reynolds, J., and Haffner, P. (Eds.). (2006). Atlas of Crayfish in Europe. Paris: Muséum national d'Historie naturelle.

Conflict of Interest: The authors declare that the research was conducted in the absence of any commercial or financial relationships that could be construed as a potential conflict of interest.

Publisher's Note: All claims expressed in this article are solely those of the authors and do not necessarily represent those of their affiliated organizations, or those of the publisher, the editors and the reviewers. Any product that may be evaluated in this article, or claim that may be made by its manufacturer, is not guaranteed or endorsed by the publisher.

Copyright (c) 2021 Theissinger, Edsman, Maguire, Diéguez-Uribeondo and Jussila. This is an open-access article distributed under the terms of the Creative Commons Attribution License (CC BY). The use, distribution or reproduction in other forums is permitted, provided the original author(s) and the copyright owner(s) are credited and that the original publication in this journal is cited, in accordance with accepted academic practice. No use, distribution or reproduction is permitted which does not comply with these terms. 